\title{
Mcl-1 promotes survival of thymocytes by inhibition of Bak in a pathway separate from Bcl-2
}

\author{
A Dunkle ${ }^{1}$, I Dzhagalov ${ }^{1}$ and $\mathrm{Y}-\mathrm{W} \mathrm{He}^{\star, 1}$
}

The antiapoptotic proteins Mcl-1 and Bcl-2 have been shown to be critical in T-cell development and homeostasis, but the precise mechanism by which these proteins function in T cells and other cells of the body is unclear. Potential mechanisms have allowed both for overlapping and unique roles for these proteins because of their abilities to bind different proapoptotic Bcl-2 family members, but it is unclear which of these mechanisms are important in an in vivo context. By generation of various genetic mouse models, we found that Mcl-1-deficient thymocytes die largely by a Bak-specific mechanism. In vivo deletion of Bak rescued the survival and developmental blocks of Mcl-1-deficient thymocytes at the double-negative and single-positive stages. Transgenic overexpression of $\mathrm{Bcl}-2$ and in vivo deletion of $\mathrm{Bax}$ or Bim were unable to rescue Mcl-1-deficient thymocytes. Thus, Mcl-1 functions in a unique pathway from Bcl-2 in T lymphocytes, likely because of its specific ability to bind and sequester proapoptotic Bak. Together, these data provide an in vivo model for Mcl-1 activity and present us with a greater understanding of the pathways that promote thymocyte survival.

Cell Death and Differentiation (2010) 17, 994-1002; doi:10.1038/cdd.2009.201; published online 8 January 2010

T lymphocytes are a dynamic population that depends on the careful regulation of apoptotic pathways for both its establishment and maintenance. In the thymus, hematopoietic precursors undergo a multistage developmental program, in which cells progress from the immature $\mathrm{CD} 4^{-} \mathrm{CD} 8^{-}$doublenegative (DN) stage, through the $\mathrm{CD} 4{ }^{+} \mathrm{CD} 8{ }^{+}$double-positive (DP) stage, to $\mathrm{CD}^{+}{ }^{+} \mathrm{CD}^{-}$or $\mathrm{CD}^{-}{ }^{-} \mathrm{CD} 8^{+}$single-positive (SP) stages before exiting the thymus into the peripheral T-cell pool. During this process, thymocytes undergo multiple selection steps to ensure that a functional, non-self-reactive T-cell receptor (TCR) is expressed on the cell surface. Classical apoptotic pathways have essential roles in thymic selection and peripheral responses, with critical implications for autoimmunity and homeostasis. ${ }^{1}$

$\mathrm{Bcl}-2$ family proteins, which are mediators of the intrinsic pathway of apoptosis, are defined by sharing one or more of four $\mathrm{Bcl}-2$ homology $(\mathrm{BH})$ domains and can be subdivided into the following three subgroups by structure and function: multidomain antiapoptotic proteins, multidomain proapoptotic proteins, and proapoptotic $\mathrm{BH} 3-$ only proteins. ${ }^{2}$ The antiapoptotic proteins, namely $\mathrm{Bcl}-2, \mathrm{Mcl}-1, \mathrm{Bcl}-\mathrm{x}_{\mathrm{L}}, \mathrm{Bcl}-\mathrm{w}$, and $\mathrm{A} 1$, share multiple $\mathrm{BH}$ regions and inhibit proapoptotic family members through interactions between $\mathrm{BH}$ domains. Proapoptotic Bak and Bax, which contain $\mathrm{BH} 1-3$ regions, form homo-oligomeric pores in the mitochondrial membrane and are critical for the release of cytochrome $c$ and downstream events, such as activation of Apaf-1 and effector caspases. ${ }^{3,4}$ $\mathrm{BH} 3-$ only proteins function as sensors of apoptotic stimuli and induce apoptosis either by directly activating Bak and Bax ('activators') or by binding antiapoptotic proteins ('sensitizers'), although the extent to which they have these different roles in vivo is still unclear. ${ }^{5-11}$

Genetic mouse models have suggested distinct roles for antiapoptotic proteins in T lymphocytes. Bcl- $2^{-/-}$thymocyte development is normal at early postnatal time points, but $\mathrm{T}$ cells in both the periphery and the thymus are lost by 4 weeks of age, likely because of differences in Bcl-2 dependency between fetal liver and bone marrow-derived hematopoietic progenitors. ${ }^{12-15}$ However, $\mathrm{Bcl}-\mathrm{x}_{\mathrm{L}}$ is not required for $\mathrm{T}$-cell development, effector function or memory, although $\mathrm{Bcl}-\mathrm{x}^{-1-} \mathrm{DP}$ thymocytes have reduced survival under some conditions. ${ }^{16-18} \mathrm{Mcl}-1$ is required for thymocyte progression past the DN stage and is also required for SP cells to reach maturation and for survival of naive and activated peripheral T cells. ${ }^{19,20}$

$\mathrm{Mcl}-1, \mathrm{Bcl}-2$, and $\mathrm{Bcl}-\mathrm{x}_{\mathrm{L}}$ are each expressed in a unique pattern in thymocytes. Mcl-1 is expressed in all thymocyte subsets. ${ }^{19,20} \mathrm{Bcl}-2$ is expressed in both DN and SP stages, but downregulated in DP until positive selection. ${ }^{21-23}$ Conversely, $\mathrm{Bcl}-\mathrm{x}_{\mathrm{L}}$, the predominant splice product of the $\mathrm{Bcl}-\mathrm{x}$ gene in thymocytes, exhibits high expression at DP but low expression at DN and SP. ${ }^{16,24}$ Given that $\mathrm{Mcl}-1$ and $\mathrm{Bcl}-2$ are expressed in DN and SP thymocytes, ${ }^{20-23}$ it was intriguing that loss of $\mathrm{Mcl}-1$ alone did not allow survival past these stages. ${ }^{19,20} \mathrm{As} \mathrm{Bcl}-2^{-/-}$thymocytes show a similar defect, ${ }^{12-15}$ it seems that both $\mathrm{Bcl}-2$ and $\mathrm{Mcl}-1$ are singly required for survival past the DN stage. This raised the question of whether $\mathrm{Bcl}-2$ and $\mathrm{Mcl}-1$ have distinct molecular roles in thymocytes. To assess this, we generated genetic models to dissect the mechanisms of Mcl-1 activity. These studies will not only yield

1Department of Immunology, Duke University Medical Center, Durham, NC 27710, USA

*Corresponding author: Y-W He, Department of Immunology, Duke University Medical Center, Jones Bldg 335, Box 3010, Research Drive, Durham, NC 27710, USA. Tel: + 919613 7870; Fax: + 919684 8982; E-mail: he000004@mc.duke.edu

Keywords: Mcl-1; Bcl-2; Bak; thymocyte survival

Abbreviations: DN, double negative; DP, double positive; SP, single positive; TCR, T-cell receptor; BH, Bcl-2 homology

Received 17.7.09; revised 05.11.09; accepted 19.11.09; Edited by JP Medema; published online 08.1.10 
insight into mechanisms of thymocyte survival but also have implications for understanding how different types of $\mathrm{Bcl}-2$ family members regulate apoptosis in vivo.

\section{Results}

Genetic models for dissecting the roles of Mcl-1. We previously developed an Mcl-1 deletion model in which exon 1 of the $\mathrm{Mcl}-1$ gene was flanked by loxP recombination sites to create 'floxed' mice $\left(\mathrm{Mcl}-1^{\mathrm{f} / \mathrm{f}}\right) .{ }^{25}$ To achieve deletion at different stages in thymic development, these mice were crossed with mice in which Cre recombinase is expressed under the proximal Lck promoter, which allows efficient deletion by the DN3 stage, or mice expressing Cre under the CD4 promoter/enhancer, which deletes by $\mathrm{DP} .{ }^{20,26} \mathrm{Mcl}-1-$ deficient lines were crossed with $\mathrm{Bcl}$-2-transgenic $\left(\mathrm{Bcl}-2^{\mathrm{tg}}\right),{ }^{27}$ $\mathrm{Bak}^{-1-28} \mathrm{Bax}^{-1-29}$ or $\mathrm{Bim}^{-1-30}$ mice to build a genetic pathway for $\mathrm{Mcl}-1$ activity and determine the in vivo interactions of these proteins in thymocytes.

Overexpression of $\mathrm{Bcl}-2$ cannot rescue $\mathrm{Mcl}-1$-deficient thymocytes. Previous observations from Mcl-1-deficient models implied that $\mathrm{Mcl}-1$ and $\mathrm{Bcl}-2$ have distinct roles at the DN stage. Alternatively, the possibility remained that endogenous levels of $\mathrm{Bcl}-2$ were insufficient to rescue the loss of Mcl-1. To investigate these possibilities, we crossed $\mathrm{Mcl}-1 / \mathrm{f} \mathrm{Cre}$ mice with mice that overexpress $\mathrm{Bcl}-2$ as a transgene under the $H-2 K^{b}$ promoter, yielding high expression in all hematopoietic cells. ${ }^{27}$ Flow cytometry confirmed expression of the $\mathrm{Bcl}-2$ transgene in DN, DP, and SP thymocytes in our system (data not shown).

In these and previous experiments, Mcl- $1^{\mathrm{f} / \mathrm{f}}$ LckCre mice exhibited a dramatic reduction $(\sim 90 \%)$ in total thymocyte number attributed to a block at DN, specifically an accumulation at the $\mathrm{CD} 44^{+} \mathrm{CD} 25^{+} \mathrm{DN} 2$ and $\mathrm{CD} 44^{-} \mathrm{CD} 25^{+} \mathrm{DN} 3$ stages (Figure 1). ${ }^{20} \mathrm{~A}$ similarly profound loss in thymocyte number was observed in $\mathrm{Mcl}-1^{\mathrm{f} / \mathrm{L}} \mathrm{LckCreBcl}-2^{\mathrm{tg}}$ mice compared with both $\mathrm{Bcl}-2^{\text {tg }}$ and wild-type controls (Figure 1a). In spite of increased thymic cellularity in $\mathrm{Bcl}-2^{\text {tg }}$ control mice, $\mathrm{Mcl}-1^{\mathrm{f} / \mathrm{f}} \mathrm{LckCreBcl}-2^{\text {tg }}$ total cell numbers were not significantly different from those of $\mathrm{Mcl}-1^{\mathrm{f} / \mathrm{f}}$ LckCre mice (Figure 1a). As previously observed, the thymic profile of $\mathrm{Mcl}-1^{\mathrm{f} / \mathrm{f}} \mathrm{LckCre}$ mice showed a skewing toward the DN compartment at the expense of DP (Figure 1b, upper panel). Although the $\mathrm{Bcl}-2$ transgene alone increased DN percentage, the block at DN is also observable in $\mathrm{Mcl}-1^{\mathrm{f} / \mathrm{f}}$ LckCreBcl- ${ }^{\mathrm{tg}}$ mice (Figure $1 \mathrm{~b}$, upper panel). In addition, the block at the DN2-DN3 stages is still observed in $\mathrm{Mcl}-1^{\mathrm{f} / \mathrm{f}}$ LckCreBcl-2 ${ }^{\mathrm{tg}}$ mice (Figure $1 \mathrm{~b}$ ).

As different thymic subsets may have different apoptotic mechanisms, we examined whether $\mathrm{Bcl}-2$ overexpression could rescue survival of Mcl-1-deficient SP thymocytes and peripheral T cells. We previously showed that $\mathrm{Mcl}-1 /{ }^{\mathrm{f} / \mathrm{f}} \mathrm{CD} 4 \mathrm{Cre}$ mice have normal cellularity in the thymus and spleen, but a marked reduction in mature SP cells as defined by the expression of TCR $\beta$ and the markers Qa2 and CD69 (mature $\mathrm{SP}$ cells $\left.=\mathrm{TCR} \beta^{+} \mathrm{Qa2}{ }^{+} \mathrm{CD} 69^{\mathrm{lo}}\right)$, as well as both $\mathrm{CD} 4^{+}$and $\mathrm{CD}^{+}{ }^{+}$T cells in the periphery. ${ }^{20}$ Similarly, $\mathrm{Mcl}-1{ }^{\mathrm{f} / \mathrm{f}} \mathrm{CD} 4 \mathrm{CreBcl}-$ $2^{\text {tg }}$ mice exhibited a loss of T cells in the spleen, although the percentage was consistently higher than $\mathrm{Mcl}-1 / \mathrm{f} / \mathrm{f} D 4 \mathrm{Cre}$
(Figure 1c-i). Similar to $\mathrm{Mcl}-1{ }^{\mathrm{f} / \mathrm{f}} \mathrm{CD} 4 \mathrm{Cre}$ mice, the thymic profile of $\mathrm{Mcl}-1^{\mathrm{f} / \mathrm{f}} \mathrm{CD} 4 \mathrm{CreBcl}-2^{\mathrm{tg}}$ mice showed a reduction in the percentage of $\mathrm{CD}^{+}{ }^{+}$and $\mathrm{CD} 8^{+} \mathrm{SP}$ cells (Figure 1c-ii) and in the percentage of $\mathrm{TCR} \beta^{+}$cells in SP compartments (Figure $1 \mathrm{c}-$ iii $\left(\mathrm{CD} 4{ }^{+} \mathrm{SP}\right)$ and $1 \mathrm{c}$-iv $\left.\left(\mathrm{CD} 8^{+} \mathrm{SP}\right)\right)$. However, within the $\mathrm{CD} 4^{+} \mathrm{TCR} \beta^{+}$and $\mathrm{CD} 8^{+} \mathrm{TCR} \beta^{+} \mathrm{SP}$ compartments, Mcl- $1^{\mathrm{t} / \mathrm{f}}$ $\mathrm{CD} 4 \mathrm{CreBcl}-2^{\text {tg }}$ had higher proportions in the mature gate than did $\mathrm{Mcl}-1^{\mathrm{f} / \mathrm{f}} \mathrm{CD} 4 \mathrm{Cre}$ (Figure $1 \mathrm{c}$-iii and $\mathrm{c}$-iv). Cell numbers of mature $\mathrm{CD}^{+}$and $\mathrm{CD}^{+} \mathrm{SP}$ cells in $\mathrm{Mcl}-1^{\mathrm{f} / \mathrm{f}} \mathrm{CD} 4 \mathrm{CreBcl}-2^{\mathrm{tg}}$ mice were also increased, but were still significantly lower than $\mathrm{Bcl}-2^{\text {tg }}$ controls (Figure 1d). The same was true for both $\mathrm{CD}^{+}{ }^{+}$and $\mathrm{CD}^{+}{ }^{+} \mathrm{T}$ cells in the spleen (Figure 1e).

As Bcl- $2^{\text {tg }}$ mice have elevated total cell numbers in both the thymus and the spleen, we compared the percentages of mature SP cells in the thymus and T cells in the spleen. For $\mathrm{CD}^{+}{ }^{+} \mathrm{SP}$ cells, there was an increase in the mean percentage of mature SP cells in the thymus of $\mathrm{Mcl}-1^{\mathrm{f} / \mathrm{f}}$ $\mathrm{CD} 4 \mathrm{CreBcl}-2^{\text {tg }}$ mice from that of $\mathrm{Mcl}-1^{\mathrm{f} / \mathrm{f}} \mathrm{CD} 4 \mathrm{Cre}$ mice, although the percentage was significantly lower than that of $\mathrm{Bcl}-2^{\text {tg }}$ control (Figure 1f, left). For $\mathrm{CD}^{+} \mathrm{SP}$ cells, the percentage of mature cells in the thymus was not significantly different from that of $\mathrm{Mcl}-1{ }^{\mathrm{f} / \mathrm{f}} \mathrm{CD} 4 \mathrm{Cre}$ (Figure 1f, right). The same results were observed for $\mathrm{CD}^{+}{ }^{+}$and $\mathrm{CD} 8^{+} \mathrm{T}$ cells, respectively, in the spleen (Figure $1 \mathrm{~g}$ ). These data show that although overexpression of Bcl-2 lends a modest improvement to survival of Mcl-1-deficient SP thymocytes and peripheral $\mathrm{T}$ cells, particularly $\mathrm{CD}^{+}{ }^{+}$cells, there is still a significant impairment in the survival of these cells as the transgene is unable to rescue percentages to wild-type or $\mathrm{Bcl}-2^{\text {tg }}$ control levels.

$\mathrm{Bak}^{-I-}$ partially rescues thymocyte defect in $\mathrm{Mcl}-1^{\mathrm{f} / \mathrm{f}}$ LckCre mice, whereas $\mathrm{Bax}^{-I-}$ cannot. One explanation for the nonredundancy of $\mathrm{Mcl}-1$ and $\mathrm{Bcl}-2$ is that these proteins have differential abilities to bind proapoptotic proteins. For example, the BH3-only protein Noxa binds Mcl-1 and $\mathrm{A} 1$ but not $\mathrm{Bcl}-2$ or $\mathrm{Bcl}-\mathrm{x}_{\mathrm{L}}{ }^{6,9}$ Intriguingly, Bak has been shown to bind $\mathrm{Mcl}-1$ at relatively high affinity, $\mathrm{Bcl}-\mathrm{x}_{\mathrm{L}}$ at a lower affinity, and did not bind Bcl-2 to a detectable level. ${ }^{31}$ However, a different group recently showed that when the Bak protein as opposed to the Bak $\mathrm{BH} 3$ peptide ${ }^{31}$ was used, Bcl-2 could bind Bak with similar or better affinity than $\mathrm{Bcl}-\mathrm{x}_{\mathrm{L}}$, although this was somewhat dependent on the variant of Bcl-2. ${ }^{32}$ Therefore, the in vivo specificity of Bak for $\mathrm{Mcl}-1$ is unclear. To determine whether the death of Mcl1-deficient thymocytes occurred preferentially through Bak, we crossed $\mathrm{Mcl}-1^{\mathrm{f} / \mathrm{f}} \mathrm{LckCre}$ mice with $\mathrm{Bak}^{-1-}$ and $\mathrm{Bax}^{-1-}$ mice. Although some groups, but not others, have observed a mild expansion in total cellularity of the $\mathrm{Bax}^{-1-}$ thymus, ${ }^{29,33}$ we observed no differences between wild-type and Bak or Bax single knockouts (not shown), and therefore all Crenegative genotypes are represented as controls in our experiments.

Total thymocyte numbers in $\mathrm{Mcl}-1^{\mathrm{f} / \mathrm{f}} \mathrm{LckCreBak}^{-1-}$ mice were significantly increased over $\mathrm{Mcl}-1^{\mathrm{f} / \mathrm{f}} \mathrm{LckCreBak}^{+/-}$, although the numbers did not reach control levels

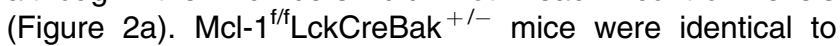
age-matched $\mathrm{Mcl}-1^{\mathrm{f} / \mathrm{f}}$ LckCre mice (data not shown). Thymic cellularity of $\mathrm{Mcl}-1^{\mathrm{f} / \mathrm{f}} \mathrm{LckCreBax}^{-1-}$ mice was no different from that of $\mathrm{Mcl}-1^{\mathrm{f} / \mathrm{f}} \mathrm{LckCre}$ (Figure $2 \mathrm{~b}$ ). To determine which stages 
a

Total Thymus

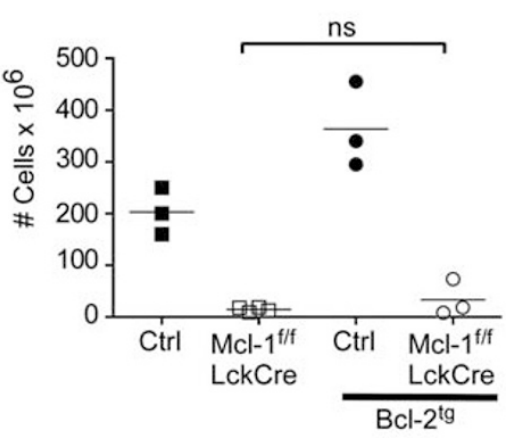

c

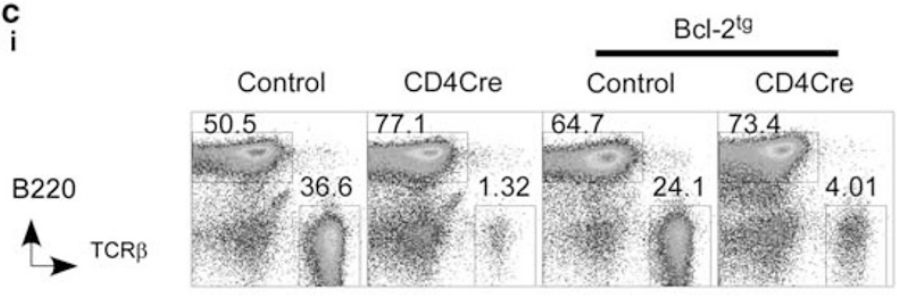

ii
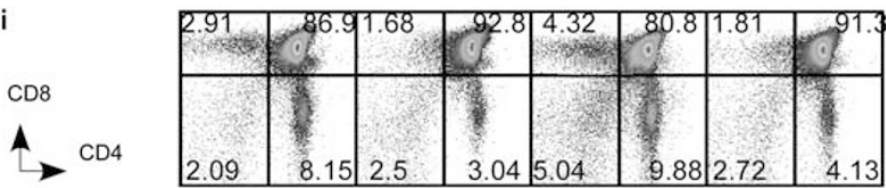

iii

\# cells

$\longrightarrow$ TCR

CD4 SP

$\stackrel{\text { Qa2 }}{\longrightarrow C 69}$

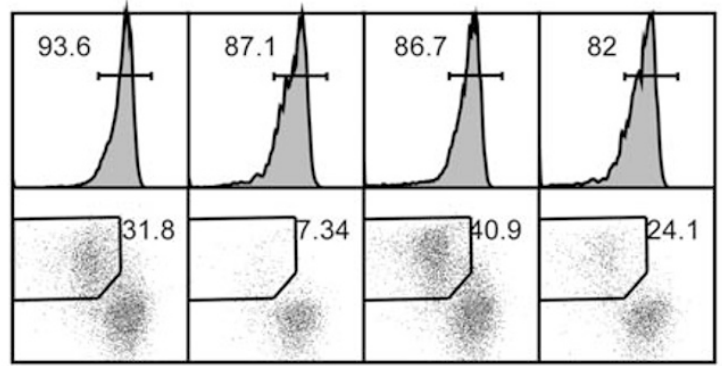

iv

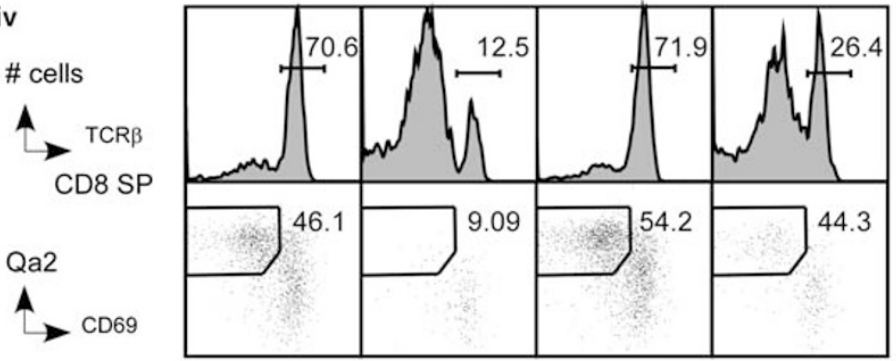
Total Thymus

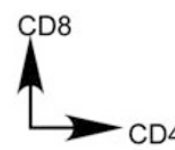
DN Gated

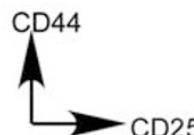

CD25
Control $\quad \mathrm{Mcl}-1^{\mathrm{f} / \mathrm{L}} \mathrm{LckCre}$ 57.7 $\mathrm{Mcl}-1^{\mathrm{f} / \mathrm{f}} \quad \mathrm{Mcl}-1^{\mathrm{f} / \mathrm{f}}$ LckCre

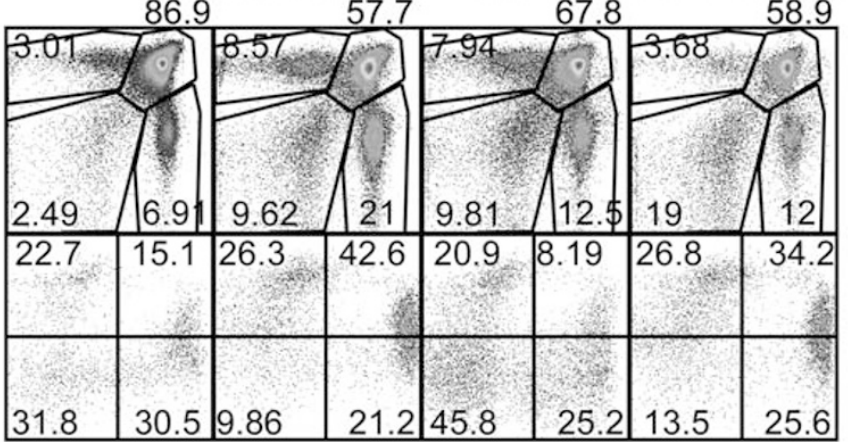

d
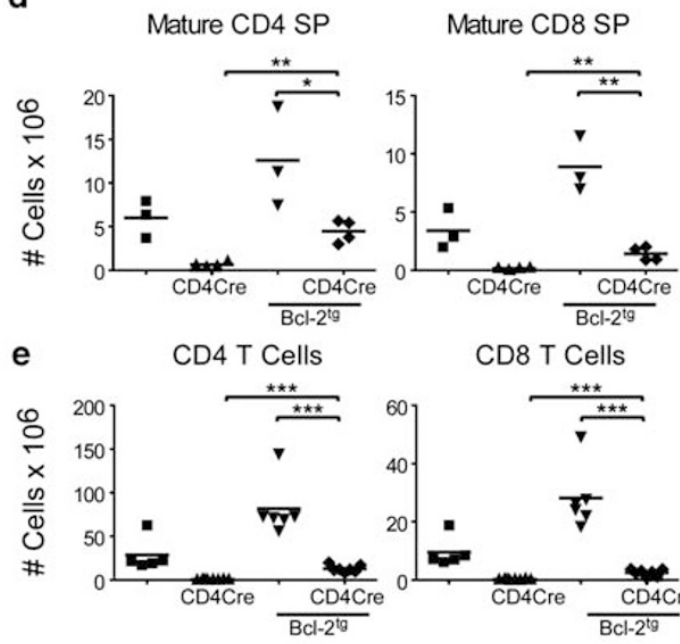

CD8 T Cells

f

Mature CD4 SP
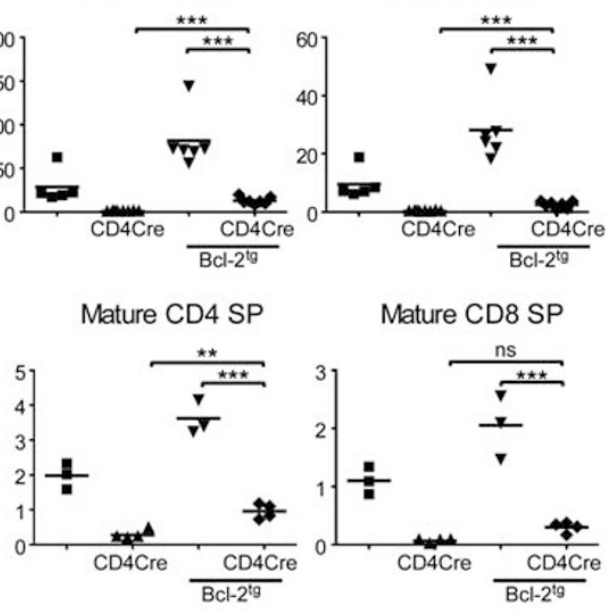

g

CD4 T Cells

CD8 T Cells
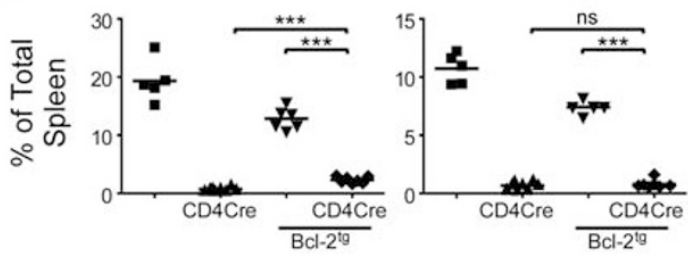

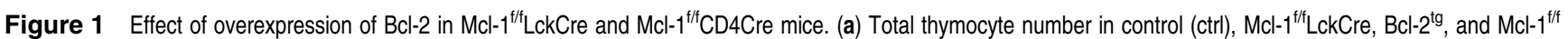
LckCreBcl-2 $2^{\text {tg }}$ mice. Control is Mcl-1/f or Mcl- $1^{+/+}$. (b) Representative FACS plots of control, Mcl-1 $1^{t / f} \mathrm{LckCre}, \mathrm{Bcl}-2^{\mathrm{tg}}$, and Mcl- $1^{\mathrm{t} / \mathrm{L}} \mathrm{LckCreBcl}-2^{\mathrm{tg}}$ mice. Top panel: CD4 versus CD8 staining of total thymus. Numbers represent the percentage of total. Lower panel: CD44 and CD25 expression in DN cells. Numbers represent the percentage of DN.

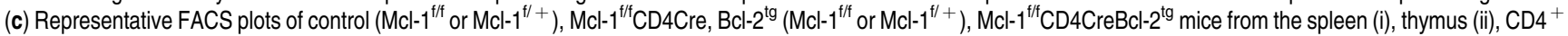
SP-gated thymocytes (iii), and CD8 ${ }^{+}$SP thymocytes (iv). Qa2 versus CD69 SP plots were pregated on TCR $\beta^{+}$. Numbers represent the percentage of total (i, ii) or pregated populations (iii, iv). ( $\left(\right.$ and $\mathbf{e}$ ) Total number of mature $\left(\mathrm{TCR} \beta^{+} \mathrm{Qa2} 2^{+} \mathrm{CD} 69^{\circ}\right) \mathrm{CD} 4^{+}$and CD8 ${ }^{+} \mathrm{SP}$ cells in the thymus (panel d) and $\mathrm{CD} 4^{+}$and $\mathrm{CD} 8^{+} \mathrm{T}$ cells $\left(\mathrm{TCR} \beta^{+}\right.$) in the spleen (panel e) of control, Mcl-1/f/f CD4Cre, Bcl-2 $2^{\mathrm{tg}}, \mathrm{Mcl}-1^{\mathrm{t} / \mathrm{C}} \mathrm{CD} 4 \mathrm{CreBcl}-2^{\mathrm{tg}}$ mice. (f and g) Percentage of mature $\left(\mathrm{TCR} \beta^{+} \mathrm{Qa2} 2^{+} \mathrm{CD} 69^{1 /}\right) \mathrm{CD}^{+}$and CD8 ${ }^{+} \mathrm{SP}$ cells in total thymus (panel f) and percentage $\mathrm{CD} 4^{+}$and $\mathrm{CD} 8^{+} \mathrm{T}$ cells $\left(\mathrm{TCR} \beta^{+}\right.$) in total spleen (panel g) of control, Mcl- $1^{\mathrm{f} / \mathrm{C}} \mathrm{CD} 4 \mathrm{Cre}, \mathrm{Bcl}-2^{\mathrm{tg}}, \mathrm{Mcl}-1^{\mathrm{t} / \mathrm{C}} \mathrm{CD} 4 \mathrm{CreBcl}-2^{\mathrm{tg}} \mathrm{mice}$. For panels c-g, 'CD4Cre' represents Mcl- $1{ }^{\text {t/f }} \mathrm{CD} 4 \mathrm{Cre}$. All mice were 5-8 weeks of age and data represent two (LckCre) or five (CD4Cre) separate experiments. $n=3-4$ (LckCre) and $n=5-8$ (CD4Cre), Q22 versus CD69 not available for all experiments. For all graphs, line represents mean total/percentage. $P$-value is illustrated as ${ }^{\star} P<0.05,{ }^{\star}{ }^{*} P<0.01$, ${ }^{\star \star \star} P<0.001$, or not significant ' $\mathrm{ns}$ '. Mcl- ${ }^{1 / f} \mathrm{CD} 4 \mathrm{Cre}$ and $\mathrm{Mcl}-1^{1 / 4} \mathrm{LckCre}$ were significant from control by all measures displayed 
a Total Thymus
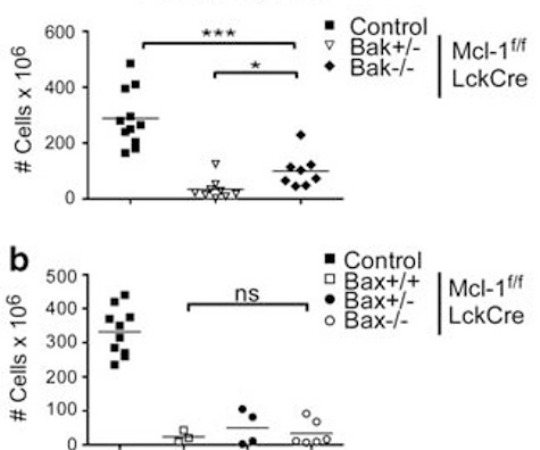

d
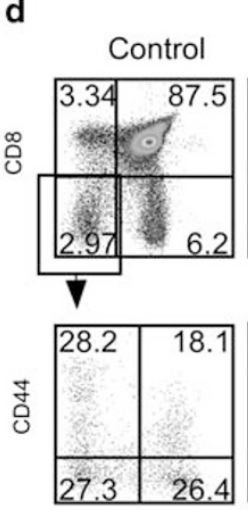

$\mathrm{Mcl}-1^{\mathrm{f} / \mathrm{f}} \mathrm{LckCre}$

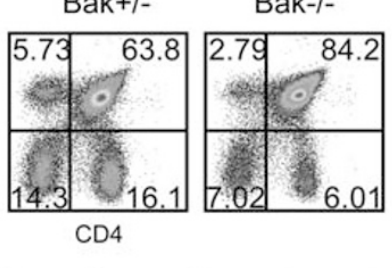

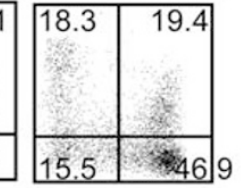

e $\mathrm{Mcl}-1^{\mathrm{f} / \mathrm{f}} \mathrm{LckCre}$

Bax-/-
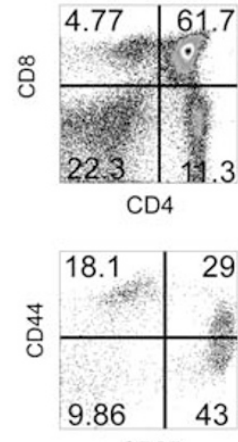

C
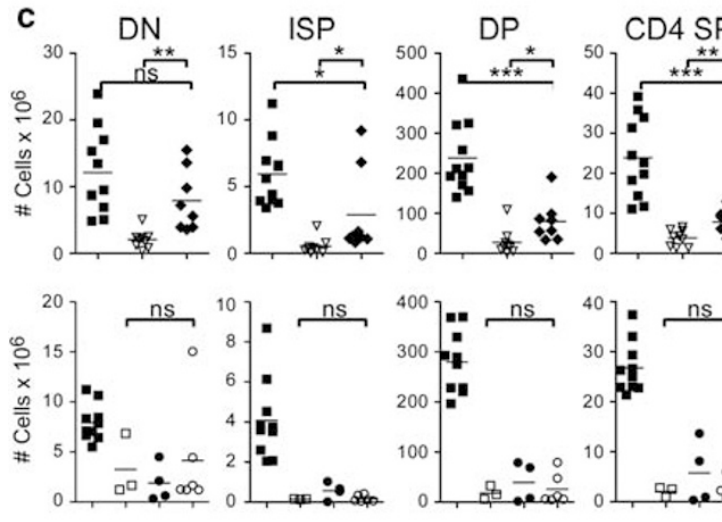

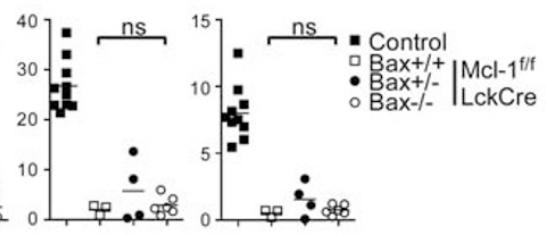

f

$\mathrm{CD} 25$

Mcl-1 Expression
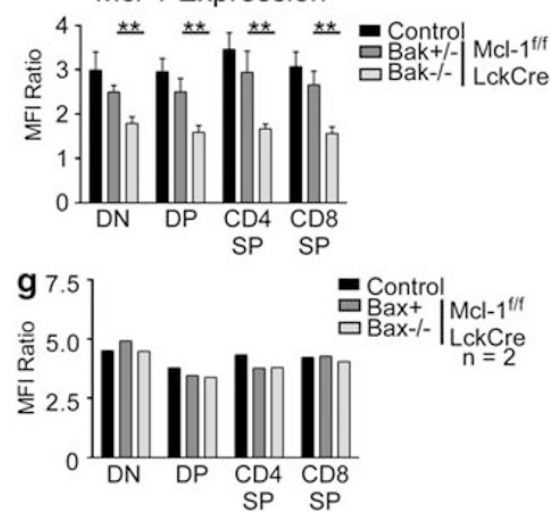

Figure 2 Thymic phenotype of $\mathrm{Bak}^{-1-}$ or Bax ${ }^{-1-}$ mice crossed with Mcl-1//fLckCre. (a and $\left.\mathbf{b}\right)$ Total thymic cellularity of control, Mcl-1//f LckCreBak ${ }^{+/-}$, and

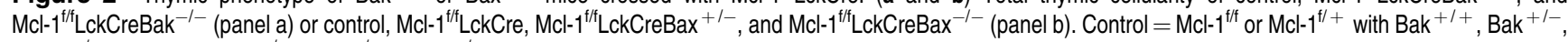
or Bak ${ }^{-l-}$ (panel a) or Bax ${ }^{+1+}, \mathrm{Bax}^{+l-}$, or Bax ${ }^{-l-}$ (panel b). (c) Total numbers of thymic subsets: DN, immature single positive (ISP $\left.=\mathrm{CD} 4^{-} \mathrm{CD} 8^{+} \mathrm{TCR} \beta^{-}\right), \mathrm{DP}, \mathrm{CD} 4 \mathrm{SP}$,

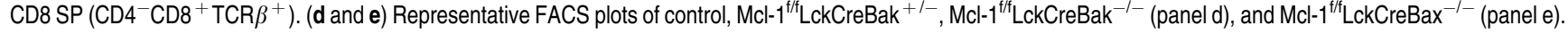
(f and $\mathbf{g}$ ) Mcl-1 expression in thymic subsets. Mcl-1 expression measured by the MFI ratio of anti-Mcl-1 to rabbit IgG control. Bars are mean + S.D. All mice were 4-7 weeks old and represent five separate experiments each for $\mathrm{Bak}^{-1-}$ and $\mathrm{Bax}^{-l-} . n=8-11$ (Bak) and $n=3-10$ (Bax); ns, not significant; $P$-value is illustrated as ${ }^{*} P<0.05$, ${ }^{\star *} P<0.01,{ }^{* \star *} P<0.001$

of thymocyte development were rescued, we compared cellularity in different thymic subsets. $\mathrm{Mcl}-1^{\mathrm{f} / \mathrm{f}} \mathrm{LckCreBak}^{-/-}$ mice had equivalent DN thymocyte numbers to control mice (Figure 2c, upper row), but in subsequent developmental subsets, cellularity in $\mathrm{Mcl}-1^{\mathrm{f} / \mathrm{f}} \mathrm{LckCreBak}^{-/-}$mice did not reach that of controls. However, there was a significant increase in Mcl- $1^{\mathrm{f} / \mathrm{f}} \mathrm{LckCreBak}^{-/-}$cell numbers over Mcl- ${ }^{\mathrm{f} / \mathrm{f}} \mathrm{LckCreBak}^{+/-}$ in all subsets except for CD8 ${ }^{+} \mathrm{SP}$, indicating some persistence of rescued cells into later stages (Figure 2c, upper row). Cell numbers in $\mathrm{Mcl}^{\mathrm{f}} \mathbf{1}^{\mathrm{f}} \mathrm{LckCreBax}^{-1-}$ mice were not different from those in $\mathrm{Mcl}-1^{\mathrm{f} / \mathrm{f}}$ LckCre mice for any subset (Figure 2c, lower row).

FACS profiling of the $\mathrm{Mcl}-1^{\mathrm{f} / \mathrm{f}} \mathrm{LckCreBak}^{-/-}$thymus revealed increased DP percentage and decreased DN percentage compared with the $\mathrm{Mcl}-1^{\mathrm{f} / \mathrm{f}} \mathrm{LckCreBak}^{+/-}$profile (Figure 2d). Consistent with a partial rescue, $\mathrm{Mcl}-1^{\mathrm{f} / \mathrm{f}}$ LckCreBak $^{-1-}$ had a higher percentage of $\mathrm{CD} 44^{-} \mathrm{CD} 25^{-}$ DN4 cells than did Mcl-1 ${ }^{\mathrm{f} / \mathrm{f}} \mathrm{LckCreBak}^{+/-}$, but the increased percentage at the DN3 stage was not completely relieved (Figure 2d). $\mathrm{Mcl}-1^{\mathrm{f} / \mathrm{f}} \mathrm{LckCreBax}^{-1-}$ showed no relief in the DN block as observable by the percentage of DN/DP or the DN profile (Figure 2e). In fact, in most experiments, Mcl- $1^{\mathrm{f} / \mathrm{f}}$
LckCreBax $^{-1-}$ contained higher percentages in the DN gate than did $\mathrm{Mcl}-1^{\mathrm{f} / \mathrm{f}} \mathrm{LckCreBax}^{+}$, although $\mathrm{Bax}^{-1-}$ alone has no such increase. ${ }^{33}$

Finally, we examined $\mathrm{Mcl}-1$ protein levels in thymocyte subsets to confirm that $\mathrm{Mcl}-1^{\mathrm{t} / \mathrm{f}} \mathrm{LckCreBak}^{-1-}$ thymocytes have not retained $\mathrm{Mcl}-1$ expression. We previously showed that we were able to specifically detect $\mathrm{Mcl}-1$ protein by flow cytometry. ${ }^{20}$ Owing to differences in background (isotype control) levels between thymic subsets, relative $\mathrm{Mcl}-1$ levels are displayed as a ratio of the mean fluorescence intensity of the $\mathrm{Mcl}-1$ stain to that of the isotype control for each subset. $\mathrm{Mcl}-1^{\mathrm{f} / \mathrm{f}} \mathrm{LckCreBak}^{+/-}$thymocytes contain wild-type levels of Mcl-1, likely because surviving thymocytes have escaped deletion of $\mathrm{Mcl}-1$ (Figure 2f). This is consistent with previous results shown by western blot or PCR in $\mathrm{Mcl}-1^{\mathrm{f} / \mathrm{f}} \mathrm{LckCre}$ mice. ${ }^{19,20} \mathrm{Mcl}-1^{\mathrm{f} / \mathrm{f}} \mathrm{LckCreBak}^{-/-}$thymocytes have a detectable and statistically significant decrease in the $\mathrm{Mcl}-1$ expression ratio in all major subsets, indicating that these cells have survived without $\mathrm{Mcl}-1$ (Figure 2f). No such decrease is detectable in $\mathrm{Mcl}-1^{\mathrm{f} / \mathrm{f}} \mathrm{LckCreBax}^{-/-}$, indicating that most of the cells in these mice are those that have escaped deletion (Figure $2 \mathrm{~g}$ ). 
$\mathrm{Bak}^{-I-}$ but not $\mathrm{Bax}^{-I-}$ rescues survival of $\mathrm{Mcl}-1^{\mathrm{f} / \mathrm{f}} \mathrm{CD} 4 \mathrm{Cre}$ mature SP thymocytes in a dose-dependent manner. Given the rescue of Mcl-1-deficient DN cells by $\mathrm{Bak}^{-1-}$ and that we continued to detect increased cell numbers in later subsets, we sought to determine whether $\mathrm{Bak}^{-1-}$ could rescue survival of $\mathrm{Mcl}-1$-deficient mature SP cells. Thymus and spleen samples obtained from $\mathrm{Mcl}-1^{\mathrm{f} / \mathrm{f}}$ CD4Cre mice had normal cellularity and this was unaltered by deletion of Bak or Bax (Figure 3a). The percentage of $\mathrm{T}$ cells in the $\mathrm{Mcl}-1^{\mathrm{f} / \mathrm{f}} \mathrm{CD} 4 \mathrm{CreBak}^{-/-}$spleen returned to near control levels, and a partial increase over $\mathrm{Mcl}-1{ }^{\mathrm{f} / \mathrm{f}} \mathrm{CD} 4 \mathrm{Cre}$ was observed in mice heterozygous for Bak (Figure $3 b$ ). We observed a return of $\mathrm{Qa2}{ }^{+} \mathrm{CD} 9^{\mathrm{lo}}$ cells in $\mathrm{CD} 4^{+}$and $\mathrm{CD} 8{ }^{+}$ $\mathrm{SP}$ compartments in both $\mathrm{Mcl}-1^{\mathrm{f} / \mathrm{f}} \mathrm{CD} 4 \mathrm{CreBak}{ }^{+/-}$and $\mathrm{Mcl}-1^{\mathrm{f} / \mathrm{f}}$ $\mathrm{CD}_{4 \mathrm{CreBak}^{-1}}$ mice (Figure $3 \mathrm{~b}$ ). Similar to what was observed with the $\mathrm{Bcl}-2$ transgene, $\mathrm{Mcl}-1^{\mathrm{f} / \mathrm{f}} \mathrm{CD} 4 \mathrm{CreBax}{ }^{-l-}$ mice exhibited a modest improvement over $\mathrm{Mcl}-1{ }^{\mathrm{f} / \mathrm{f}} \mathrm{CD} 4 \mathrm{Cre}$ in the percentage of $\mathrm{T}$ cells in the spleen and percentage of $\mathrm{Qa2}{ }^{+} \mathrm{CD} 9^{\text {lo }}$ cells within the already reduced SP compartments (Figure 3c). However, this did not match even the $\mathrm{Bak}^{+/-}$in the extent of rescue. $\mathrm{Bak}^{-1-}$ rescued $\mathrm{Mcl}-1^{\mathrm{f} / \mathrm{f}} \mathrm{CD} 4 \mathrm{Cre}$ mature $\mathrm{CD} 4^{+}$and $\mathrm{CD}{ }^{+}$SP cell numbers to wild-type levels and a dose effect was observed in Bak ${ }^{+/-}$ mice (Figure 3d). The same results were observed in the spleen, although the $\mathrm{Bak}^{+/-}$effect was not significant in $\mathrm{CD}^{+} \mathrm{T}$ cells (Figure $3 \mathrm{e}$ ). Although there was a statistically significant increase in the number of mature $\mathrm{CD}^{+} \mathrm{SP}$ and $\mathrm{CD}^{+}{ }^{+}$and $\mathrm{CD}^{+}{ }^{+} \mathrm{T}$ cells in $\mathrm{Mcl}-1^{\mathrm{f} / \mathrm{f}} \mathrm{CD} 4 \mathrm{CreBax}^{-/-}$, the absolute difference in cell numbers was minor, and $\mathrm{Mcl}-1^{\mathrm{f} / \mathrm{f}}$ $\mathrm{CD}_{4} \mathrm{CreBax}^{-1-}$ was significantly different from $\mathrm{Mcl}-1$ sufficient controls for all subsets (Figure $3 f$ and $g$ ).

Loss of Bim does not rescue Mcl-1-deficient thymocytes. One of the proposed roles of antiapoptotic proteins is to inhibit $\mathrm{BH}$-only proteins, such as Bim, that are capable of directly activating Bak and Bax. ${ }^{7,8} \mathrm{Bim}$ is known to be critical for preventing autoimmunity because of its roles in thymocyte-negative selection and activated $\mathrm{T}$ cells. ${ }^{30,34,35}$

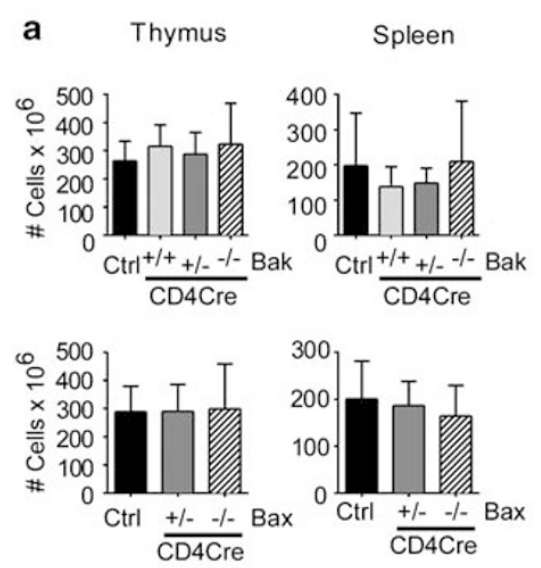

b

$\mathrm{Mcl}-\mathrm{f}^{\text {f/f }} \mathrm{CD} 4 \mathrm{Cre}$ Control Bak+/+ Bak+l- Bak-/-

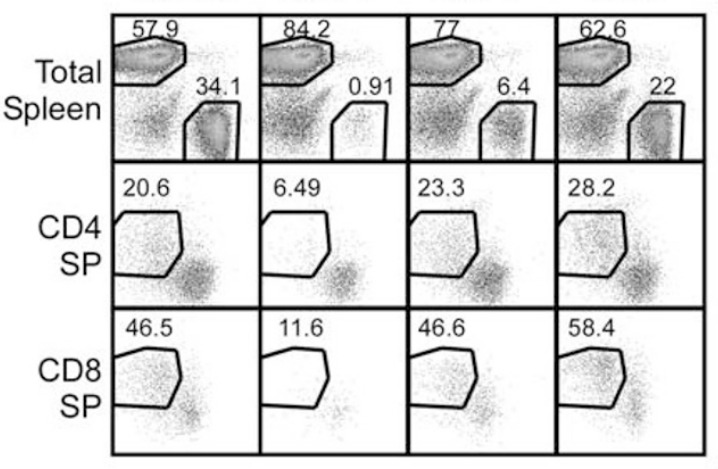

c

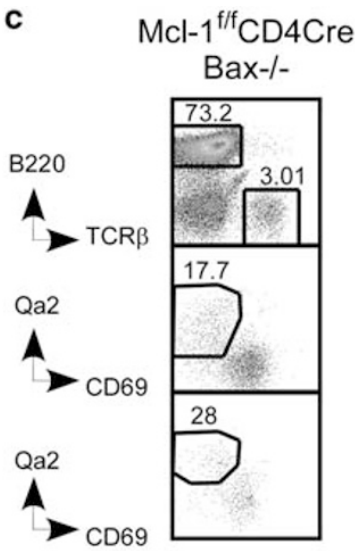

d
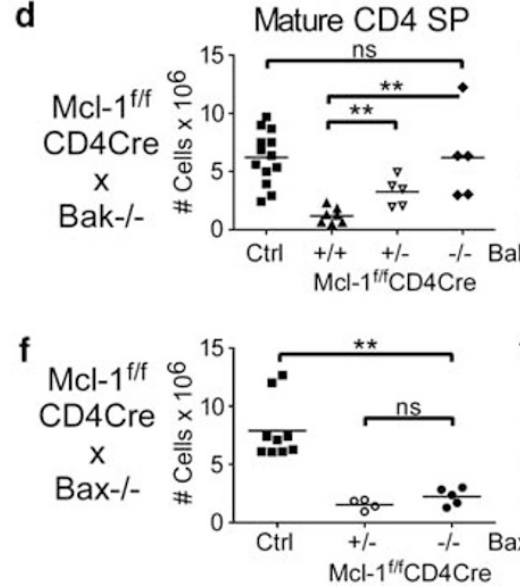

Mature CD8 SP
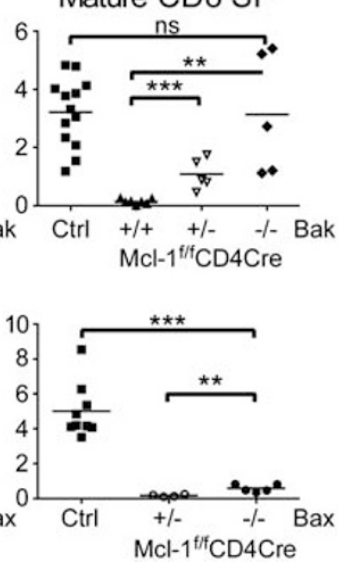
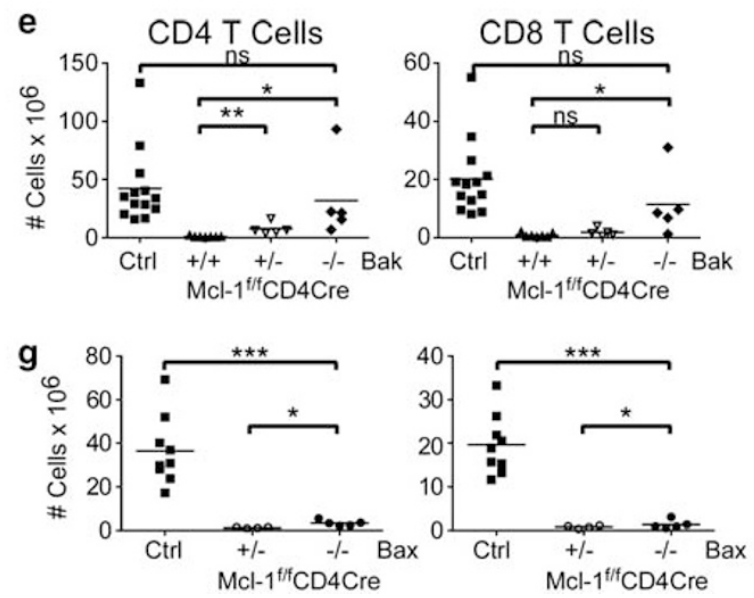

Figure 3 Phenotype of the thymus and spleen from $\mathrm{Bak}^{-1-}$ or Bax ${ }^{-1-}$ mice crossed to $\mathrm{Mcl}-1^{\mathrm{t} / \mathrm{C}} \mathrm{CD} 4 \mathrm{Cre}$. (a) Total cell numbers in the thymus and spleen of $\mathrm{Mcl}-1^{1 / f} \mathrm{CD} 4 \mathrm{Cre}$

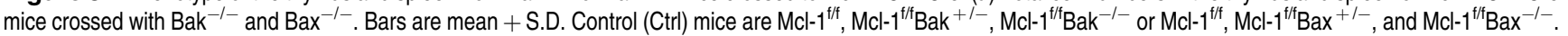

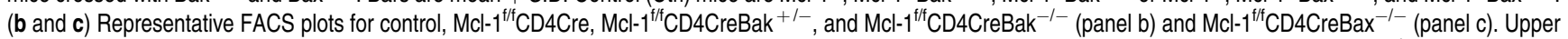
row shows the percentage of T cells $\left(\mathrm{TCR} \beta^{+}\right)$and $\mathrm{B}$ cells $\left(\mathrm{B} 22 \mathrm{O}^{+}\right)$in the spleen. Middle and bottom rows show the percentage of $\mathrm{Qa2}{ }^{+} \mathrm{CD} 69^{\text {lo }}$ mature cells in $\mathrm{CD} 4{ }^{+} \mathrm{TCR} \beta^{+} \mathrm{SP}$ compartment (middle) and $\mathrm{CD} 8^{+} \mathrm{TCR} \beta^{+} \mathrm{SP}$ compartment (bottom) in the thymus. (d and e) Total cell numbers of mature TCR $\beta^{+} \mathrm{Qa2} 2^{+} \mathrm{CD} 69^{\mathrm{lo}} \mathrm{SP}$ cells in the thymus (panel d) and $\mathrm{CD} 4^{+}$and CD8 ${ }^{+} \mathrm{T}$ cells in the spleen (panel e) of Mcl- $1^{\mathrm{f} / \mathrm{C}} \mathrm{CD} 4 \mathrm{CreBak}$ mice. (f and $\mathbf{g}$ ) Total cell numbers of mature TCR $\beta^{+} \mathrm{Qa2}{ }^{+} \mathrm{CD} 69^{\mathrm{lo}} \mathrm{SP}$ cells in the thymus (panel $\mathrm{f}$ ) and $\mathrm{CD}^{+}$and $\mathrm{CD} 8^{+} \mathrm{T}$ cells in the spleen (panel $\mathrm{g}$ ) of $\mathrm{Mcl-}{ }^{\mathrm{ft} / \mathrm{f}} \mathrm{CD} 4 \mathrm{CreBax}$ mice. Mice were $5-7$ weeks of age and represent seven (Bak) or four (Bax) separate experiments. $n=5-13$ (Bak) or $n=5-9$ (Bax) per group; ns, not significant; $P$-value is illustrated as ${ }^{*} P<0.05,{ }^{* \star} P<0.01,{ }^{* \star *} P<0.001$ 
Moreover, it has been shown that loss of Bim can rescue the survival and phenotypic defects of $\mathrm{Bcl}-2^{-/-}$mice, including thymocyte development. ${ }^{36,37}$ To determine whether Bim is important for apoptosis of Mcl-1-deficient thymocytes, we crossed $\mathrm{Mcl}-1^{\mathrm{f} / \mathrm{f}} \mathrm{CD} 4 \mathrm{Cre}$ mice with $\mathrm{Bim}^{-/-}$mice. Although there was no difference between $\mathrm{Bim}^{+/+}$and $\mathrm{Bim}^{+/-}$by our measures, $\mathrm{Bim}^{-1-}$ and $\mathrm{Mcl}-1^{\mathrm{f} / \mathrm{f}} \mathrm{CD} 4 \mathrm{CreBim}^{-1-}$ mice had higher total cell numbers in the spleen and thymus (Figure 4a). FACS profiling showed that $\mathrm{Bim}^{-1-}$ control mice had normal T-cell percentages in the spleen but increased percentages of $\mathrm{Qa}_{2}{ }^{+} \mathrm{CD} 9^{\mathrm{lo}}$ mature cells within the SP compartments (Figure $4 \mathrm{~b}$, compared with Figures 1c and $3 \mathrm{~b})$. However, $\mathrm{Mcl}-1^{\mathrm{f} / \mathrm{f}} \mathrm{CD} 4 \mathrm{CreBim}^{-1-}$ mice showed a similar percentage of mature SP cells and peripheral $T$ cells to $\mathrm{Mcl}-1^{\mathrm{t} / \mathrm{f}} \mathrm{CD} 4 \mathrm{Cre}$ (Figure 4b, compared with Figures $1 \mathrm{c}$ and $3 \mathrm{~b}$ ). In spite of increased total cellularity, $\mathrm{Mcl}-1^{\mathrm{t} / \mathrm{f}} \mathrm{CD} 4 \mathrm{CreBim}^{-1-}$ mice displayed comparable cell numbers to $\mathrm{Mcl}-1^{\mathrm{f} / \mathrm{f}} \mathrm{CD} 4 \mathrm{CreBim}{ }^{+}$ in the mature SP (Figure 4c) and spleen T-cell (Figure 4d) compartments. Thus, Bim does not seem to have a downstream role in promoting the death of $\mathrm{Mcl}$-1-deficient thymocytes.

\section{Discussion}

By generating various genetic models, we showed that $\mathrm{Mcl}-1$ and $\mathrm{Bcl}-2$ have separate molecular roles at two critical points in thymic development. Overexpression of $\mathrm{Bcl}-2$ was unable to rescue the survival of $\mathrm{Mcl}-1$-deficient thymocytes at either the DN or the SP stage. In addition, although it has been shown that $\mathrm{Bim}^{-1-}$ can rescue Bcl-2-deficient thymocytes, ${ }^{37}$ $\mathrm{Bim}^{-1-}$ was unable to rescue $\mathrm{Mcl}-1$-deficient thymocytes, and thus Bim does not seem to be the downstream effector of cell death in the absence of $\mathrm{Mcl}-1$. Intriguingly, $\mathrm{Bak}^{-1-}$ but not $\mathrm{Bax}^{-1-}$ could rescue $\mathrm{Mcl}-1$-deficient thymocytes at both the DN and SP stages, yielding evidence that specific antagonism of Bak may be the major role of Mcl-1 in thymocytes.

An in vivo model for Mcl-1 activity in $\mathrm{T}$ cells. Two opposing but not necessarily exclusive models have emerged for the mechanism of the antiapoptotic molecules $\mathrm{Bcl}-2$, Mcl-1, and Bcl- $\mathrm{x}_{\mathrm{L}}$. The 'direct-activation model' suggests that antiapoptotic proteins function to inhibit the activity of BH3-only activator proteins (Figure $5 \mathrm{a}$ ).$^{8-10}$ By this model, certain BH3-only molecules, namely Bim, Bid, and possibly Puma, directly activate Bak and Bax and binding of the antiapoptotic proteins to these $\mathrm{BH}$-only activators inhibits apoptotic pathways. ${ }^{8-10}$ Alternatively, under the 'Bak/Bax sequestration' model, the antiapoptotic proteins function to bind Bak and Bax directly to prevent their oligomerization and/or activation (Figure $5 \mathrm{~b}$ ). ${ }^{5}$ By this model, all $\mathrm{BH} 3$-only proteins function upstream to affect the ability of antiapoptotic proteins to bind Bak/Bax and the distinction between 'activators' and 'sensitizers' really lies in the differential abilities of the $\mathrm{BH} 3$-only proteins to bind antiapoptotic proteins. .,6,31 $^{5}$ a
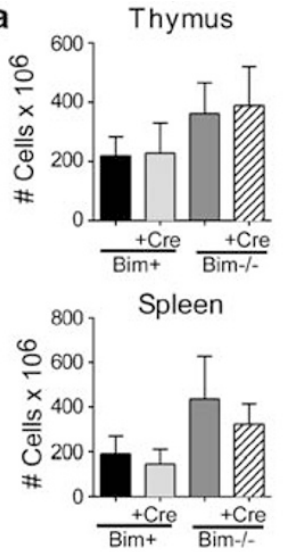

b
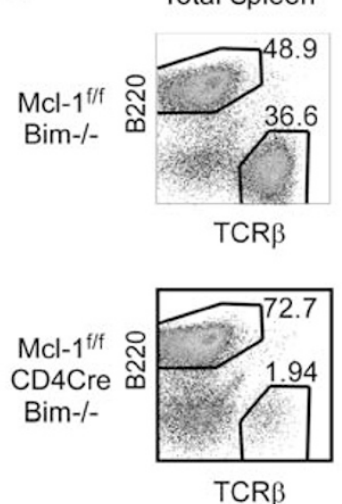

CD4 SP

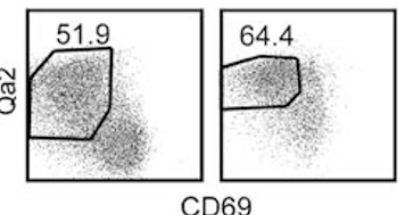

CD69

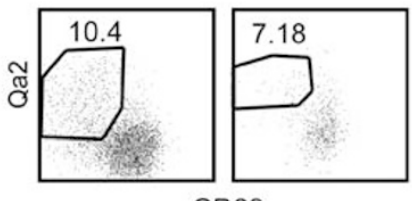

CD69
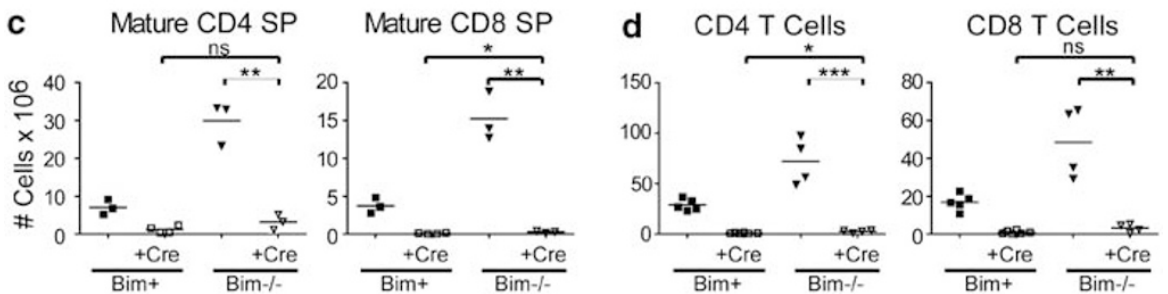

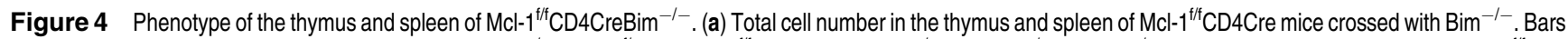

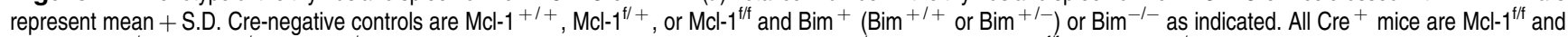
$\mathrm{Bim}^{+}\left(\mathrm{Bim}^{+l+}\right.$ or Bim $\left.{ }^{+l-}\right)$ or Bim ${ }^{-l-}$ as indicated. (b) Representative FACS plots of Bim ${ }^{-l-}$ control and $\mathrm{Mcl}-1^{f / 5} \mathrm{CD}^{+} \mathrm{CreBim}^{-l-}$. The left side shows the percentage of $\mathrm{T}$ cells $\left(\mathrm{TCR} \beta^{+}\right)$and $\mathrm{B}$ cells $\left(\mathrm{B} 220^{+}\right)$in the spleen. The right side shows percentage $\mathrm{Qa2}{ }^{+} \mathrm{CD} 69^{\text {lo }}$ mature cells in the $\mathrm{CD} 4^{+} \mathrm{TCR} \beta^{+} \mathrm{SP}$ compartment (middle) and $\mathrm{CD} 8^{+} \mathrm{TCR} \beta^{+} \mathrm{SP}$ compartment (far right). (c and d) Numbers of mature TCR $\beta^{+} \mathrm{Qa2}{ }^{+} \mathrm{CD} 69^{\circ} \mathrm{SP}$ cells in the thymus (panel c) and $\mathrm{CD} 4^{+}$and $\mathrm{CD} 8^{+} \mathrm{T}$ cells in the spleen (panel d) of Mcl-1/f/ $\mathrm{CD} 4 \mathrm{CreBim}$. Mice were $4-8$ weeks of age and represent four separate experiments. $n=4-7$; ns, not significant; $P$-value is illustrated as ${ }^{*} P<0.05$, ${ }^{\star \star} P<0.01,{ }^{* \star \star} P<0.001$ 
a

BH3-only direct activation

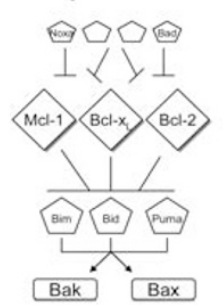

b Bak/Bax Sequestration

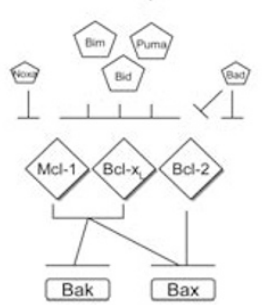

C DN thymocytes

DP thymocytes

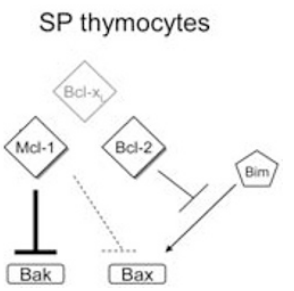

Figure 5 Models for the activity of antiapoptotic proteins. Antiapoptotic proteins are displayed as diamonds, $\mathrm{BH} 3$-only proteins are pentagons with larger symbols representing putative 'activators', and smaller symbols representing 'sensitizers,' and Bak and Bax are symbolized as rectangles. (a) 'Direct activation model' The antiapoptotic proteins $\mathrm{Mcl}-1, \mathrm{Bcl}-2$, and $\mathrm{Bcl}-\mathrm{x}_{\mathrm{L}}$ inhibit activator $\mathrm{BH} 3$-only proteins Bim, Bid, and possibly Puma, which can directly activate Bak and Bax. Sensitizer BH3-only proteins, such as Noxa and Bad, have varying specificities and affect the availability of antiapoptotic proteins. (b) 'Bak/Bax sequestration model'. The antiapoptotic proteins directly inhibit activation of Bak and Bax by binding and sequestering them from activation and/or homo-oligomerization. BH3-only proteins effect the interaction and have varying strengths because of their ability to neutralize different antiapoptotic proteins. (c) Diagram of the major roles of antiapoptotic proteins throughout thymic development

One limitation of the studies leading to these models is that specific interactions between the Bcl-2 family members have been largely defined using $\mathrm{BH} 3$ peptides and were performed in cell lines, ${ }^{6,31}$ and further studies are required to examine the in vivo consequences of these interactions. Recent data obtained from knock-in mice expressing mutant forms of Bim suggest that both its ability to bind antiapoptotic proteins (indirect activation) and its ability to bind Bax (direct activation) are important for its full apoptotic effects. ${ }^{11}$ The data we presented in this study allow us to build an in vivo pathway of the roles of $\mathrm{Mcl}-1$ in thymocytes (Figure $5 \mathrm{c}$ ). Our data support previous biochemical data showing specificity at the level of the Mcl-1Bak interaction. ${ }^{31}$ Together, these results are supportive of a model in which $\mathrm{Mcl}-1$ directly sequesters Bak in thymocytes. We showed that loss of the direct activator Bim does not rescue $\mathrm{Mcl}-$ 1-deficient thymocytes, although this does not rule out the possibility that other BH3-only 'activators' may be downstream of Mcl-1. However, Bid and Puma have both been shown to activate Bax and $\mathrm{Bak}^{3,10}$ and our data show that $\mathrm{Mcl}$-1-deficient thymocytes die by a Bak-specific mechanism. Release of BH3only proteins upon deletion of $\mathrm{Mcl}-1$ may still contribute to the death of thymocytes, particularly in DN cells in which rescue by $\mathrm{Bak}^{-1-}$ was incomplete. It is possible that one of these $\mathrm{BH}$-only proteins could preferentially activate Bak over Bax, either directly or indirectly, by a mechanism that is yet to be appreciated. Future studies should continue to explore which other Bcl-2-family proteins contribute to the death of Mcl-1deficient cells. However, the robust rescue by $\mathrm{Bak}^{-1-}$ is suggestive of a major role of $\mathrm{Mcl}-1$ in thymocytes being that of directly antagonizing Bak.
The role of $\mathrm{Mcl}-1$ seems to be slightly different in each thymic subset. In DN cells, Mcl-1 sequesters Bak, and loss of Mcl-1 leads to Bak activation (Figure 5c, left). As rescue by $\mathrm{Bak}^{-1-}$ is only partial at this stage, it is likely that Mcl-1 also inhibits other apoptotic signals that are less selective for Bak, such as BH3-only proteins that directly activate Bak/Bax (as shown in Figure 5c). Although our data do not directly address the role of $\mathrm{Bcl}-2$, published data place Bim genetically downstream of $\mathrm{Bcl}-2$, and suggest that the major role of $\mathrm{Bcl}-2$ in thymocytes is to inhibit the activation of Bax and/or Bak by Bim (Bax activation displayed in Figure $5 \mathrm{c}$ ). It is likely that Bim functions both directly to activate Bax and indirectly because mutant forms of Bim that cannot bind Bax partially alleviate the $\mathrm{Bcl}-2^{-1-}$ phenotype but do not entirely recapitulate the rescue observed with the $\mathrm{Bim}^{-1-} .{ }^{11}$ In data not presented, we observed that $\mathrm{Bim}^{-1-}$ does not appear to rescue $\mathrm{Mcl}-1^{\mathrm{f} / \mathrm{f}}$ LckCre thymocytes, and therefore Bim alone is unlikely to be responsible for the incomplete rescue of $\mathrm{Mcl}$-1-deficient cells at DN. In DP cells, both $\mathrm{Mcl}-1$ and $\mathrm{Bcl}-\mathrm{x}_{\mathrm{L}}$ can sequester Bak (Figure 5c, middle), as suggested by biochemical data ${ }^{31}$ and our previous data in which DP cells were lost when both Mcl-1 and $\mathrm{Bcl}-\mathrm{x}$ were deleted. ${ }^{20}$ It is unclear whether $\mathrm{Mcl}-1$ and $\mathrm{Bcl}-\mathrm{x}_{\mathrm{L}}$ also inhibit Bax in DP thymocytes or whether Bax is inactive at this stage. In SP cells, direct inhibition of Bak seems to be a more dominant role of $\mathrm{Mcl}-1$ because of the extent of rescue by deletion of Bak, even at the heterozygous level (Figure $5 \mathrm{c}$, right). As $\mathrm{Bcl}-2^{\text {tg }}$ and $\mathrm{Bax}^{-1-}$ yielded a slight improvement in SP thymocyte survival, $\mathrm{Mcl}-1$ likely also has a minor cooperative role with $\mathrm{Bcl}-2$ in inhibiting Bax (Figure $5 \mathrm{c}$, right). As this was not observed in $\mathrm{Bim}^{-1-}$, it could suggest that direct inhibition Bax by $\mathrm{Mcl}-1$ is responsible, although $\mathrm{Mcl}-1$ could inhibit one of the other activator $\mathrm{BH} 3$-only proteins for this effect. Although not displayed in Figure $5 \mathrm{c}$ for simplicity, upstream BH3-only proteins have important roles in affecting the ability of antiapoptotic proteins to perform the functions displayed.

Nonredundancy of $\mathrm{Bcl}-2$ family members. The rescue of Mcl-1-deficient thymocytes by the Bak knockout mice was somewhat surprising considering that Bak and Bax are presumed to be largely redundant. ${ }^{28}$ Neither Bak nor Bax single knockout mice display a significant phenotype, whereas the double knockout mice have profound defects in several systems, including thymocytes. ${ }^{28,29,33}$ However, there is some evidence that Bak and Bax, although performing similar functions, may be regulated differently. Under resting conditions, Bak is localized on the mitochondrial membrane, whereas Bax can be found in the cytosol until induction of apoptosis when it relocates to the mitochondrial membrane, coincident with a conformational shift to the active form and multimerization. ${ }^{38-40}$ Although hard evidence is still required, on a conceptual level, this could allow for Bak and Bax to be subjected to different regulatory mechanisms. In addition, although our study focuses on the roles of the Bcl-2 family members, other proteins may affect the activity of Bak and/or Bax. Mitochondrial protein VDAC2 has been shown to bind monomeric Bak in the mitochondrial membrane and contribute to the susceptibility of cells to apoptosis through Bak. ${ }^{41,42}$ 
Specific roles for $\mathrm{Mcl}-1$ in different cell types. It was interesting that we observed a more complete rescue of $\mathrm{Mcl}$ 1-deficient thymocytes by $\mathrm{Bak}^{-1-}$ in SP cells than in DN cells, indicating that even between different thymic subsets, the dominant activity of $\mathrm{Mcl}-1$ is different. Similarly, the minor rescue observed in $\mathrm{Bcl}^{-2^{\mathrm{tg}}}$ and $\mathrm{Bax}^{-1-} \mathrm{SP}$ thymocytes was more evident in $\mathrm{CD}^{+}$cells than in $\mathrm{CD}^{+}$cells, indicating that $\mathrm{CD} 4^{+}$and $\mathrm{CD} 8^{+}$cells may have a different balance between $\mathrm{Mcl}-1$-specific and $\mathrm{Mcl}-1 / \mathrm{Bcl}-2$-shared pathways. Recently, a mouse model was published in which specific promoter regions of $\mathrm{Mcl}-1$ were mutated leading to reduced expression of Mcl-1 in thymocytes and peripheral T cells. ${ }^{43}$ The phenotype in this hypomorphic mouse was more severe in $\mathrm{CD} 8^{+}$cells than in $\mathrm{CD} 4^{+} \mathrm{T}$ cells, correlating well with our data that $\mathrm{CD}^{+}$cell survival was not improved by $\mathrm{Bax}^{-1-}$ or $\mathrm{Bcl}-2^{\text {tg }}$. These data suggest that $\mathrm{CD}^{+}{ }^{+} \mathrm{T}$ cells are more exclusively dependent on $\mathrm{Mcl}-1$ cells than are $\mathrm{CD}^{+}{ }^{+} \mathrm{T}$ cells. In addition to T cells, Mcl-1 is required for neutrophil survival. ${ }^{25}$ Interestingly, it was recently published that the Bak/Bax double knockout rescued Mcl-1-deficient neutrophil survival, but unlike what we observed in thymocytes, the authors stated that neither Bak nor Bax knockout alone rescued it. ${ }^{44} \mathrm{Mcl}-1$-deficient neutrophils were not rescued by $\mathrm{Bim}^{-1-}$, but $\mathrm{Bim}^{-1-}$ could rescue activated $\mathrm{Mcl}-1-$ deficient macrophages in their system. ${ }^{44}$

The reasons for differences in the roles of Mcl-1 between different cell types are not yet clear. However, as the balance between antiapoptotic and proapoptotic factors is what ultimately determines cell fate, a likely contributor would be differences in expression and activity of other Bcl-2 family members between cell types. Upstream BH3-only proteins inhibit antiapoptotic proteins and can combine to sensitize the cell toward certain stimuli. For example, although neither Noxa nor Bad alone could cause apoptosis in certain experimental systems, the coexpression of these proteins or their $\mathrm{BH} 3$ regions led to cell death. ${ }^{6,31} \mathrm{Bad}$ has been shown to bind $\mathrm{Bcl}-2$ and $\mathrm{Bcl}-\mathrm{x}_{\mathrm{L}}$ but not $\mathrm{Mcl}-1$ directly, whereas Noxa binds $\mathrm{Mcl}-1$ and $\mathrm{A} 1$ but not $\mathrm{Bcl}-\mathrm{x}_{\mathrm{L}}$ or Bcl-2. ${ }^{6}$ Thus, Bad could indirectly influence the role of $\mathrm{Mcl}-1$ in that the more Bad activity there is in a cell, the less $\mathrm{Bcl}-2$ and $\mathrm{Bcl}-\mathrm{x}_{\mathrm{L}}$ are able to perform shared roles with $\mathrm{Mcl}-1$ and the more susceptible the cell becomes to loss of $\mathrm{Mcl}-1$ protein or function. In addition, the activity of Noxa, which inhibits Mcl-1, is likely to have a large role in determining the availability of $\mathrm{Mcl}-1$ to perform its specific roles as well as shared roles with $\mathrm{Bcl}-2$. As biochemical pathways are further defined, it will be important to consider that each cell type and condition may have a different balance of Bcl-2 family members. Given the importance of the $\mathrm{Bcl}-2$ family in lymphoid and other systems, as well as the current interest in this family as targets of cancer therapy, it will be critical to continue to delineate roles of antiapoptotic proteins in vivo in different cell types.

\section{Materials and Methods}

Mice. Generation of $\mathrm{Mcl}-1^{\mathrm{t} / \mathrm{f}}$ mice was previously described. ${ }^{25} \mathrm{Mcl}-1$-floxed mice were backcrossed seven generations with C57BL/6 mice. LckCre and CD4Cre mice ${ }^{26}$ were obtained from Taconic (Hudson, NY, USA). Bak, ${ }^{28} \mathrm{Bax}^{29}$ and Bim ${ }^{30}$ knockout mice were obtained from the Jackson Laboratory (Bar Harbor, ME, USA). $B C l-2$-transgenic mice ${ }^{27}$ were provided by Dr. Motonari Kondo. With the exception of $\mathrm{BCl}-2^{\text {tg }}$ lines, all mice were on C57BL/6 background. For each experiment, littermate controls were used or age-matched controls substituted as necessary. All mice were analyzed between 4 and 8 weeks of age. Mice were maintained in barrier, specific pathogen-free facilities. All experiments were conducted under the guidelines approved by the Duke University Institutional Animal Care and Use Committee.

Cell counts and flow cytometry. Both the thymus and spleen were harvested in the FACS buffer (PBS containing $2 \% \mathrm{FBS}$ and $0.2 \% \mathrm{NaN}_{3}$ ) and kept on ice. Single-cell suspensions were made by smashing organs with a plunger and passing cells through a nylon mesh. Red blood cells were lysed using the ACK buffer. Cells were enumerated on a hemacytometer in $0.1 \%$ Trypan Blue. Fc receptors were blocked by $10-15$ min of incubation with $24 \mathrm{G} 2$ supernatant. Cells were stained for 20-30 min with antibodies to various surface markers (CD4, CD8, $\mathrm{CD} 69, \mathrm{Qa2}, \mathrm{TCR} \beta$, B220, CD44, CD25) directly conjugated to the fluorochromes FITC, PE, PE/Cy5, PE/Cy7, APC, or APC/Cy7. All antibodies were obtained from eBioscience (San Diego, CA, USA) or BioLegend (San Diego, CA, USA) and were used at a concentration of $0.125-0.5 \mu \mathrm{l}$ per $10^{6}$ cells in $100 \mu \mathrm{l}$. For analysis, cells were washed and resuspended in FACS buffer containing $2 \mu \mathrm{g} / \mathrm{ml}$ propidium iodide for exclusion of dead cells and run on a BD FACSCanto cytometer (BD Biosciences, San Jose, CA, USA). All analyses were performed on FloJo software (Tree Star Inc., Ashland, OR, USA).

Intracellular staining for $\mathbf{M c l}-1$. Cells were fixed after surface staining in $2 \%$ PFA for 20-60 min, washed and stored in FACS buffer at $4^{\circ} \mathrm{C}$. Fixed cells were permeabilized for $20 \mathrm{~min}$ in FACS buffer with $0.1 \%$ Saponin, $5 \%$ normal donkey serum (Jackson Immunoresearch, West Grove, PA, USA), and 10\% $24 \mathrm{G} 2$ supernatant. Cells were stained with $0.1 \mu \mathrm{g}$ per $10^{6}$ cells in $100 \mu \mathrm{l}$ with rabbit polyclonal anti-Mcl-1 (Rockland Inc., Gilbertsville, PA, USA) or $0.1 \mu \mathrm{g}$ Rabbit IgG (Rockland Inc.) for 30-60 min in the same buffer. Cells were washed with $0.1 \%$ Saponin in FACS buffer and stained with $1 \mu \mathrm{l}$ per $10^{6}$ cells FITC-donkey-anti-rabbit (Jackson Immunoresearch) for $30 \mathrm{~min}$ in $0.1 \%$ Saponin. Cells were run immediately after washing on a BD FACSCanto cytometer.

Statistical analyses. Data were further analyzed and graphed using Prism (Graphpad Software, San Diego, CA, USA). Statistical significance was defined by $P$-values $<0.05$ as calculated by unpaired two-tailed $t$-tests.

\section{Conflict of interest}

The authors declare no conflict of interest.

Acknowledgements. This study was supported by the National Institute of Health Grant nos Al073947 and Al074754.

1. Zhang N, Hartig H, Dzhagalov I, Draper D, He YW. The role of apoptosis in the development and function of T lymphocytes. Cell Res 2005; 15: 749-769.

2. Adams JM, Cory S. The Bcl-2 protein family: arbiters of cell survival. Science 1998; 281: $1322-1326$.

3. Kuwana T, Mackey MR, Perkins G, Ellisman MH, Latterich M, Schneiter R et al. Bid, Bax, and lipids cooperate to form supramolecular openings in the outer mitochondrial membrane. Cell 2002; 111: 331-342.

4. Wei MC, Zong WX, Cheng EH, Lindsten T, Panoutsakopoulou V, Ross AJ et al. Proapoptotic BAX and BAK: a requisite gateway to mitochondrial dysfunction and death. Science 2001; 292: 727-730.

5. Willis SN, Fletcher Jl, Kaufmann T, van Delft MF, Chen L, Czabotar PE et al. Apoptosis initiated when BH3 ligands engage multiple Bcl-2 homologs, not Bax or Bak. Science 2007; 315: 856-859.

6. Chen L, Willis SN, Wei A, Smith BJ, Fletcher JI, Hinds MG et al. Differential targeting of prosurvival $\mathrm{Bcl}-2$ proteins by their $\mathrm{BH}$-only ligands allows complementary apoptotic function. Mol Cell 2005; 17: 393-403.

7. Cheng EH, Wei MC, Weiler S, Flavell RA, Mak TW, Lindsten T et al. BCL-2, BCL-X(L) sequester $\mathrm{BH} 3$ domain-only molecules preventing $\mathrm{BAX}$ - and BAK-mediated mitochondrial apoptosis. Mol Cell 2001; 8: 705-711.

8. Letai A, Bassik MC, Walensky LD, Sorcinelli MD, Weiler S, Korsmeyer SJ. Distinct BH3 domains either sensitize or activate mitochondrial apoptosis, serving as prototype cancer therapeutics. Cancer Cell 2002; 2: 183-192.

9. Kuwana T, Bouchier-Hayes L, Chipuk JE, Bonzon C, Sullivan BA, Green DR et al. BH3 domains of BH3-only proteins differentially regulate Bax-mediated mitochondrial membrane permeabilization both directly and indirectly. Mol Cell 2005; 17: 525-535. 
10. Kim H, Rafiuddin-Shah M, Tu HC, Jeffers JR, Zambetti GP, Hsieh JJ et al. Hierarchical regulation of mitochondrion-dependent apoptosis by $\mathrm{BCL}-2$ subfamilies. Nat Cell Biol 2006; 8: 1348-1358.

11. Merino D, Giam M, Hughes PD, Siggs OM, Heger K, O'Reilly LA et al. The role of BH3-only protein Bim extends beyond inhibiting Bcl-2-like prosurvival proteins. J Cell Biol 2009; 186 355-362.

12. Veis DJ, Sorenson CM, Shutter JR, Korsmeyer SJ. Bcl-2-deficient mice demonstrate fulminant lymphoid apoptosis, polycystic kidneys, and hypopigmented hair. Cell 1993; 75 229-240.

13. Nakayama K, Nakayama K, Negishi I, Kuida K, Shinkai Y, Louie MC et al. Disappearance of the lymphoid system in Bcl-2 homozygous mutant chimeric mice. Science 1993; 261: 1584-1588.

14. Matsuzaki Y, Nakayama K, Nakayama K, Tomita T, Isoda M, Loh DY et al. Role of bcl-2 in the development of lymphoid cells from the hematopoietic stem cell. Blood 1997; 89: 853-862.

15. Nakayama K, Nakayama K, Negishi I, Kuida K, Sawa H, Loh DY. Targeted disruption of Bcl-2 alpha beta in mice: occurrence of gray hair, polycystic kidney disease, and lymphocytopenia. Proc Natl Acad Sci USA 1994; 91: 3700-3704.

16. Ma A, Pena JC, Chang B, Margosian E, Davidson L, Alt FW et al. Bclx regulates the survival of double-positive thymocytes. Proc Natl Acad Sci USA 1995; 92: 4763-4767.

17. Motoyama N, Wang F, Roth KA, Sawa H, Nakayama K, Nakayama K et al. Massive cell death of immature hematopoietic cells and neurons in Bcl-x-deficient mice. Science 1995; 267: $1506-1510$

18. Zhang N, He YW. The antiapoptotic protein Bcl-xL is dispensable for the development of effector and memory T lymphocytes. J Immunol 2005; 174: 6967-6973.

19. Opferman JT, Letai A, Beard C, Sorcinelli MD, Ong CC, Korsmeyer SJ. Development and maintenance of B and T lymphocytes requires antiapoptotic MCL-1. Nature 2003; 426 : 671-676.

20. Dzhagalov I, Dunkle A, He YW. The anti-apoptotic Bcl-2 family member Mcl-1 promotes T lymphocyte survival at multiple stages. J Immunol 2008; 181: 521-528.

21. Gratiot-Deans J, Ding L, Turka LA, Nunez G. Bcl-2 proto-oncogene expression during human $T$ cell development. Evidence for biphasic regulation. J Immunol 1993; 151: 83-91.

22. Gratiot-Deans J, Merino R, Nunez G, Turka LA. Bcl-2 expression during T-cell development: early loss and late return occur at specific stages of commitment to differentiation and survival. Proc Natl Acad Sci USA 1994; 91: 10685-10689.

23. Veis DJ, Sentman CL, Bach EA, Korsmeyer SJ. Expression of the Bcl-2 protein in murine and human thymocytes and in peripheral T lymphocytes. J Immunol 1993; 151: 2546-2554.

24. Grillot DA, Merino R, Nunez G. Bcl-XL displays restricted distribution during $T$ cell development and inhibits multiple forms of apoptosis but not clonal deletion in transgenic mice. J Exp Med 1995; 182: 1973-1983.

25. Dzhagalov I, St John A, He Y-W. The antiapoptotic protein Mcl-1 is essential for the survival of neutrophils but not macrophages. Blood 2007; 109: 1620-1626.

26. Lee PP, Fitzpatrick DR, Beard C, Jessup HK, Lehar S, Makar KW et al. A critical role for Dnmt1 and DNA methylation in T cell development, function, and survival. Immunity 2001; 15: 763-774.
27. Domen J, Gandy KL, Weissman IL. Systemic overexpression of BCL-2 in the hematopoietic system protects transgenic mice from the consequences of lethal irradiation. Blood 1998; 91: 2272-2282.

28. Lindsten T, Ross AJ, King A, Zong WX, Rathmell JC, Shiels HA et al. The combined functions of proapoptotic Bcl-2 family members Bak and Bax are essential for normal development of multiple tissues. Mol Cell 2000; 6: 1389-1399.

29. Knudson CM, Tung KS, Tourtellotte WG, Brown GA, Korsmeyer SJ. Bax-deficient mice with lymphoid hyperplasia and male germ cell death. Science 1995; 270: 96-99.

30. Bouillet P, Metcalf D, Huang DC, Tarlinton DM, Kay TW, Kontgen F et al. Proapoptotic $\mathrm{Bcl}-2$ relative Bim required for certain apoptotic responses, leukocyte homeostasis, and to preclude autoimmunity. Science 1999; 286: 1735-1738.

31. Willis SN, Chen L, Dewson G, Wei A, Naik E, Fletcher Jl et al. Proapoptotic Bak is sequestered by $\mathrm{Mcl}-1$ and $\mathrm{Bcl}-\mathrm{xL}$, but not $\mathrm{Bcl}-2$, until displaced by $\mathrm{BH}$-only proteins. Genes Dev 2005; 19: 1294-1305.

32. Dai H, Meng XW, Lee S-H, Schneider PA, Kaufmann SH. Context-dependent Bcl-2/Bak interactions regulate lymphoid cell apoptosis. J Biol Chem 2009; 284: 18311-18322. M109.004770.

33. Rathmell JC, Lindsten T, Zong WX, Cinalli RM, Thompson CB. Deficiency in Bak and Bax perturbs thymic selection and lymphoid homeostasis. Nat Immunol 2002; 3: 932-939.

34. Bouillet P, Purton JF, Godfrey DI, Zhang LC, Coultas L, Puthalakath $\mathrm{H}$ et al. BH3-only Bcl-2 family member Bim is required for apoptosis of autoreactive thymocytes. Nature 2002; 415 922-926.

35. Hildeman DA, Zhu Y, Mitchell TC, Bouillet P, Strasser A, Kappler J et al. Activated T cell death in vivo mediated by proapoptotic bcl-2 family member Bim. Immunity 2002; 16 759-767.

36. Bouillet $\mathrm{P}$, Cory S, Zhang LC, Strasser A, Adams JM. Degenerative disorders caused by Bcl-2 deficiency prevented by loss of its BH3-only antagonist Bim. Dev Cell 2001; 1: 645-653

37. Wojciechowski S, Tripathi P, Bourdeau T, Acero L, Grimes HL, Katz JD et al. Bim/Bcl-2 balance is critical for maintaining naive and memory T cell homeostasis. J Exp Med 2007; 204: 1665-1675.

38. Griffiths GJ, Dubrez L, Morgan CP, Jones NA, Whitehouse J, Corfe BM et al. Cell damageinduced conformational changes of the pro-apoptotic protein Bak in vivo precede the onset of apoptosis. J Cell Biol 1999; 144: 903-914.

39. Hsu YT, Wolter KG, Youle RJ. Cytosol-to-membrane redistribution of Bax and Bcl-X(L) during apoptosis. Proc Natl Acad Sci USA 1997; 94: 3668-3672.

40. Wolter KG, Hsu Y-T, Smith CL, Nechushtan A, Xi X-G, Youle RJ. Movement of Bax from the cytosol to mitochondria during apoptosis. J Cell Biol 1997; 139: 1281-1292.

41. Cheng EH, Sheiko TV, Fisher JK, Craigen WJ, Korsmeyer SJ. VDAC2 inhibits BAK activation and mitochondrial apoptosis. Science 2003; 301: 513-517.

42. Ren D, Kim H, Tu HC, Westergard TD, Fisher JK, Rubens JA et al. The VDAC2-BAK rheostat controls thymocyte survival. Sci Signal 2009; 2: ra48.

43. Yang $\mathrm{C}-\mathrm{Y}$, Lin N-H, Lee J-M, Huang C-Y, Min H-J, Yen JJ-Y et al. Promoter knock-in mutations reveal a role of $\mathrm{Mcl}-1$ in thymocyte-positive selection and tissue or cell lineagespecific regulation of Mcl-1 expression. J Immunol 2009; 182: 2959-2968.

44. Steimer DA, Boyd K, Takeuchi O, Fisher JK, Zambetti GP, Opferman JT. Selective roles for antiapoptotic MCL-1 during granulocyte development and macrophage effector function Blood 2009; 113: 2805-2815. 